\title{
Continuing need for mineralocorticoid therapy in salt-losing congenital adrenal hyperplasia
}

\author{
I. A. HUGHeS, A. WILTON, C. A. LOLE, AND O. P. GRAY
}

Department of Child Health and Tenovus Institute, and KRUF Institute of Renal Disease, Welsh National School of Medicine, Cardiff

SUMMARY Four patients with salt-losing congenital adrenal hyperplasia (CAH) who had stopped mineralocorticoid therapy for several years, showed raised plasma concentrations of $170 \mathrm{H}$-progesterone and plasma renin activity, despite adequate glucocorticoid therapy. One patient was able to reduce urinary sodium excretion when the sodium intake was restricted. Another patient who was a salt-loser, developed signs of an adrenal crisis when salt deprived. In comparison, one nonsalt-loser and 2 normal subjects decreased urinary sodium excretion in response to sodium restriction. The addition of fludrocortisone $(100 \mu \mathrm{g})$ to usual maintenance doses of glucocorticoid, resulted in normal levels of plasma $170 \mathrm{H}$-progesterone and plasma renin activity in all 4 salt-losers. Two female salt-losers, with raised plasma testosterone concentrations, began menstruating when their plasma testosterone concentrations returned to normal after treatment with fludrocortisone. It is recommended that salt-losing $\mathrm{CAH}$ patients should be given mineralocorticoid, in addition to glucocorticoid therapy, at least until adult life.

About one-third to one-half of patients with congenital adrenal hyperplasia ( $\mathrm{CAH})$ due to $\mathrm{C} 21$ hydroxylase enzyme deficiency are salt-losers. This loss occurs within the first 2 weeks of life and patients require immediate mineralocorticoid replacement. However, they appear to require less salt later and it has been suggested that mineralocorticoid therapy can be discontinued at age 4 years (Newns, 1974). There is evidence that this regimen will lead to inadequate control in these patients. A pronounced increase in plasma concentrations of $17 \mathrm{OH}$-progesterone and plasma renin activity occurs in some salt-losers, in spite of apparently adequate glucocorticoid replacement (Hughes and Winter, 1976; Grant et al., 1977). The consequences of persistent raised levels of plasma steroid precursors are unknown. A group of salt-losing CAH patients, in whom mineralocorticoid treatment had been discontinued for several years, was studied to evaluate the metabolic responses to a restricted sodium diet and the reintroduction of mineralocorticoid therapy.

Department of Child Health and Tenovus Institute, Welsh National School of Medicine, Cardiff

I. A. HUGHES, research fellow

C. A. LOLE, dietitian

O. P. GRAY, professor of child health

KRUF Institute of Renal Disease, Royal Infirmary, Cardiff A. WILTON, research fellow

\section{Patients and methods}

Six patients with $\mathrm{CAH}$ due to C21-hydroxylase deficiency were initially included in the study. One boy, however, developed a salt-losing crisis as a result of gastroenteritis. Mineralocorticoid treatment was restarted and he was excluded from the study. Clinical details of the remaining patients are shown in Table 1. The salt-losers had hyponatraemic dehydration and hyperkalaemia soon after birth. They were treated with hydrocortisone (or cortisone acetate), fludrocortisone, and supplemental salt in the milk feeds. For comparison, a 13-year-old girl with nonsalt-losing CAH and two female student dietitians without evidence of endocrine disease were also studied.

Dietary histories were recorded for each patient, with particular reference to sodium intake. Patients were maintained on their usual doses of glucocorticoid during the study. Venous blood was collected between 0900 and 1000 hours for determination of plasma concentrations of $17 \mathrm{OH}$-progesterone, testosterone, and plasma renin activity. 24-hour urine collections were performed for measurement of sodium and potassium excretion. Patients and controls were then placed on a dietary intake of $20 \mathrm{mmol}$ sodium/day (potassium $75 \mathrm{mmol} /$ day) for 4 days under supervision in hospital. Plasma and urinary studies were repeated at the end of this 
Table 1 Clinical details of subjects studied

\begin{tabular}{lllccc}
\hline Case & $\begin{array}{l}\text { Sex } \\
(M / F)\end{array}$ & SL/NSL & $\begin{array}{l}\text { Age at study } \\
\text { (years) }\end{array}$ & $\begin{array}{l}\text { (Age fludrocortisone } \\
\text { discontinued (years) }\end{array}$ & $\begin{array}{l}\text { Years without } \\
\text { fudrocortisone }\end{array}$ \\
\hline 1 & F & SL & 9 & 4 & 5 \\
2 & F & SL & 13 & 10 & $3 \cdot 5$ \\
3 & F & SL & 14 & 8 & 6 \\
4 & M & SL & 14 & 7 & 7 \\
5 & F & NSL & 13 & - & - \\
Control & F & - & 19 & - & - \\
Control & & - & 20 & - & - \\
\hline
\end{tabular}

SL $=$ salt-loser; NSL $=$ nonsalt-loser.

period, when venous blood was collected from subjects in the standing position. Salt-losers were then treated with fludrocortisone $100 \mu \mathrm{g}$ daily in addition to their usual glucucorticoid therapy. Measurement of plasma concentrations of $170 \mathrm{H}-$ progesterone, testosterone, and plasma renin activity was repeated after 3 months.

Plasma $170 H$-progesterone was determined by radioimmunoassay using an antiserum supplied by Dr D. L. Loriaux, NIH, USA. The sensitivity of the assay was $4 \mathrm{pg} /$ tube. The intra-assay and interassay coefficients of variation were less than 6.3 and $11.9 \%$ respectively. Apart from 11-deoxycortisol $(1 \cdot 8 \%)$ and 21 -deoxycortisol $(1.6 \%)$, the crossreactivity of the antiserum with numerous other corticosteroids, including progesterone, was less than $0.1 \%$. Plasma testosterone was measured by radioimmunoassay as previously described (Hillier et al., 1973). Plasma renin activity was measured by radioimmunoassay of the angiotensin I generated after standard incubation of plasma (Haber et al., 1969). The mean level of plasma renin activity in healthy ambulant adults was $1 \cdot 17 \pm 0 \cdot 5 \mathrm{SEM} \mathrm{ng} / \mathrm{ml}$ per hour.

\section{Results}

When studied, all salt-losers were taking more than $200 \mathrm{mmol}$ sodium per day in their diet apart from table salt added to food. The results of baseline studies performed while on this sodium intake are shown in Table 2 . The mean plasma 170H-progesterone concentration in salt-losers was markedly raised, despite a hydrocortisone dose in the range of $20-32 \mathrm{mg} / \mathrm{m}^{2}$ per day (mean dose $25 \mathrm{mg} / \mathrm{m}^{2}$ per day). Two female salt-losers showed raised plasma testosterone concentrations and plasma renin activity was increased in all salt-losers. In comparison, the nonsalt-loser had normal plasma $17 \mathrm{OH}$-progesterone and testosterone concentrations and a slightly raised plasma renin activity. All values were normal in the control subjects. The effects of sodium restriction in the control subjects and the nonsaltloser (Case 5) are shown in Fig. 1. All showed a slight increase in plasma $17 \mathrm{OH}$-progesterone concentrations and a rise in plasma renin activity, which was more pronounced in the nonsalt-loser. Urinary sodium excretion decreased to approximately 20 $\mathrm{mmol} / \mathrm{day}$ in all 3 subjects in response to sodium restriction. Results obtained in one salt-loser (Case 1) are shown in Fig. 2. This patient was also able to reduce urinary sodium excretion, but the increases in plasma renin activity and plasma $170 \mathrm{H}$-progesterone were more pronounced. Fig. 3 shows the results obtained in two other salt-losers (Cases 2 and 4). Plasma 17OH-progesterone concentrations in both patients were markedly raised before the dietary period and increased further after sodium restriction. Neither patient was able to suppress urinary sodium excretion in response to a low sodium intake, nor was there an apparent change in levels of plasma renin activity. Unfortunately, neither patient in this instance was sampled for plasma renin activity in the standing position (Haber et al., 1969). The 4th salt-loser (Case 3) did not tolerate the diet (Fig. 4). Plasma 17OH-progesterone

Table 2 Plasma steroid and renin concentrations before salt restriction

\begin{tabular}{|c|c|c|c|c|}
\hline Subjects & $\begin{array}{l}17 O H P \\
(n m o l / l)\end{array}$ & $\begin{array}{l}\text { Testosterone } \\
(\mathrm{nmol} / \mathrm{l})\end{array}$ & $\begin{array}{l}\text { Plasma renin activity } \\
\text { (ng/ml per hour) }\end{array}$ & $\begin{array}{l}\text { Hydrocortisone dose } \\
\left(\mathrm{mg} / \mathrm{m}^{2} \text { per day }\right)\end{array}$ \\
\hline $\begin{array}{l}\text { Salt-losers } \\
\text { Nonsalt-loser } \\
\text { Controls }\end{array}$ & $\begin{array}{l}364 \\
3 \cdot 6 \\
4 \cdot 5\end{array}$ & $\begin{array}{l}3 \cdot 1 \\
0 \cdot 4 \\
-\end{array}$ & $\begin{array}{l}3 \cdot 3 \\
2 \cdot 2 \\
0 \cdot 74\end{array}$ & $\begin{array}{l}25 \\
21 \\
-\end{array}$ \\
\hline
\end{tabular}

$170 H P=170 H$-progesterone.

Mean values are shown (testosterone results in women only).

Conversion: SI to traditional units-17OHP: $1 \mathrm{nmol} / 1 \approx 0.31 \mathrm{ng} / \mathrm{ml}$; testosterone: $1 \mathrm{nmol} / 1 \approx 0.29 \mathrm{ng} / \mathrm{ml}$.

Traditional to SI units-angiotensin I: $1 \mathrm{ng} / \mathrm{ml}$ per hour $\approx 0.77 \mathrm{pmol} / \mathrm{ml}$ per hour. 

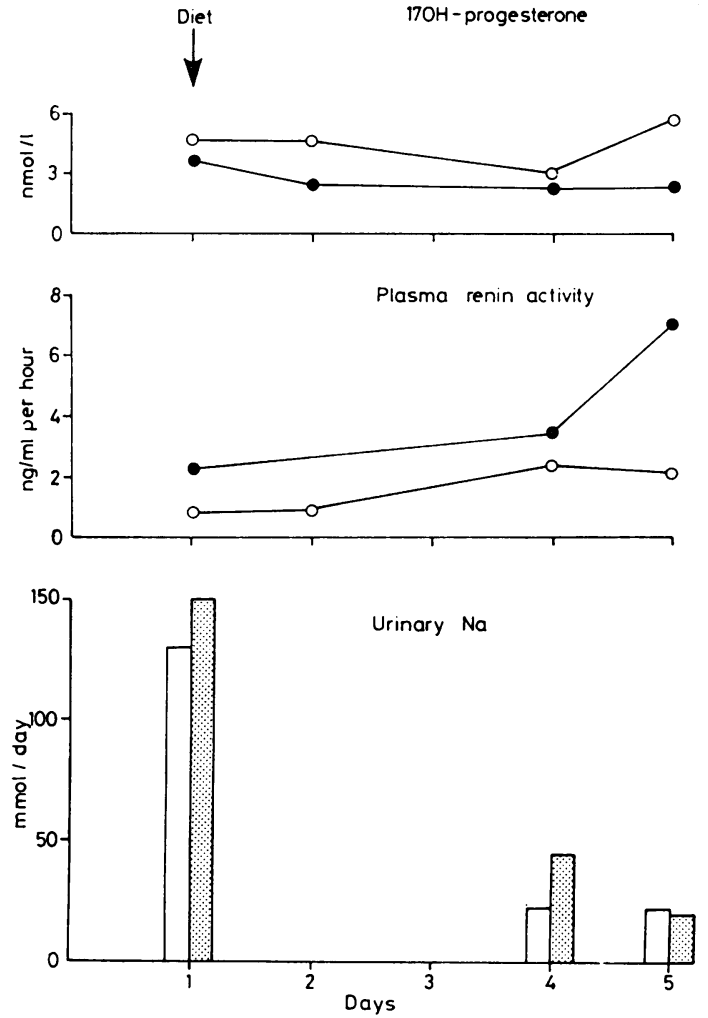

Fig. 1 Effect of sodium restriction on plasma 17OHP, plasma renin activity, and 24-hour urinary $\mathrm{Na}$ secretion in controls $\left(\square^{\circ}\right)$ and a nonsalt-loser, Case 5 (图).

concentrations increased further from the previous high values and plasma renin activity increased to $60 \mathrm{ng} / \mathrm{ml}$ per hour. There was a $3 \mathrm{~kg}$ loss in body weight and the patient showed signs of an adrenal crisis after only 2 days' salt restriction. The study was discontinued and IV saline was given. This treatment, together with subsequent fludrocortisone therapy, resulted in plasma $17 \mathrm{OH}$-progesterone concentrations and plasma renin activity returning towards normal levels and a regain to normal body weight. Urinary sodium excretion was not measured in this patient.

The results of hormone measurements performed
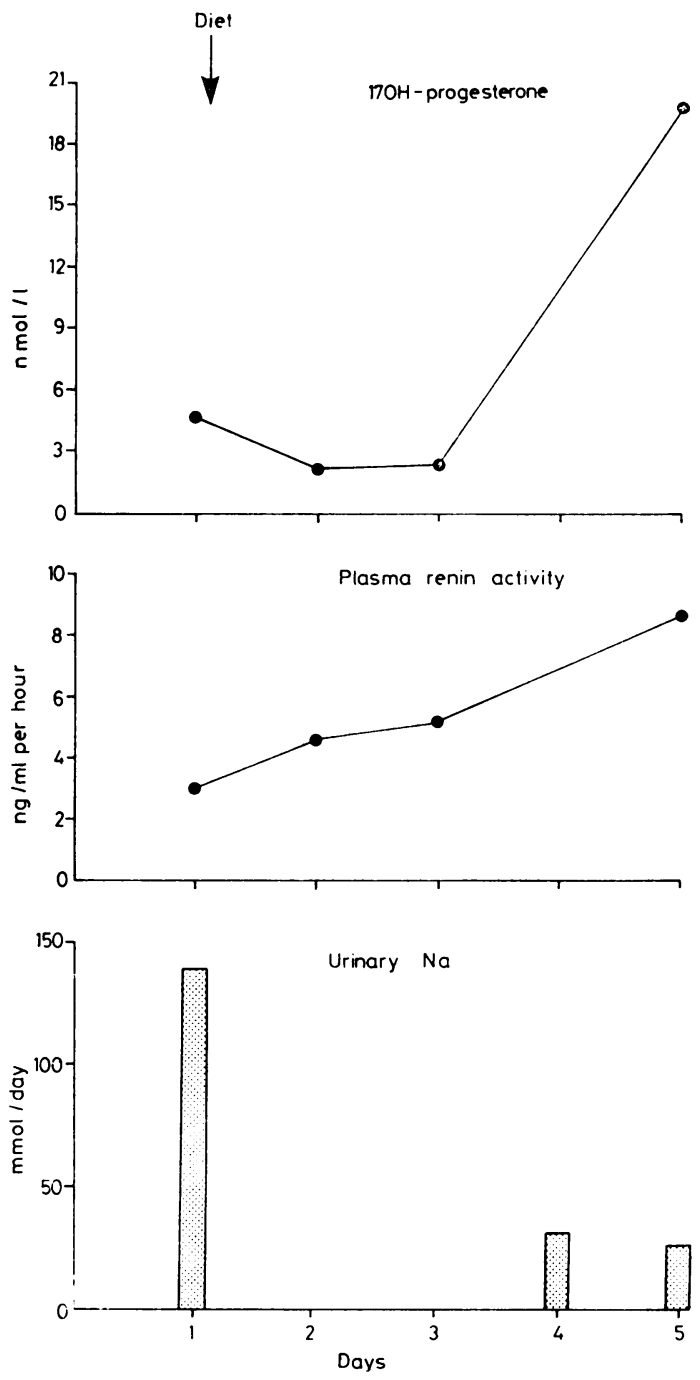

Fig. 2 Response to sodium restriction in Case 1, a salt-loser.

after 3 months of treatment with $100 \mu \mathrm{g}$ fludrocortisone are shown in Table 3. For comparison, the results of baseline studies (Table 2) are also given. The dose of glucocorticoid had remained constant

Table 3 Plasma steroid and renin concentrations before and after fludrocortisone therapy

\begin{tabular}{|c|c|c|c|c|c|c|c|c|}
\hline \multirow[t]{2}{*}{ Subjects } & \multicolumn{2}{|c|}{$\begin{array}{l}17 O H P \\
(n m o l / l)\end{array}$} & \multicolumn{2}{|c|}{$\begin{array}{l}\text { Testosterone } \\
(\mathrm{nmol} / \mathrm{l})\end{array}$} & \multicolumn{2}{|c|}{$\begin{array}{l}\text { Plasma renin activity } \\
\text { (ng/ml per hour) }\end{array}$} & \multicolumn{2}{|c|}{$\begin{array}{l}\text { Hydrocortisone dose } \\
\left(\mathrm{mg} / \mathrm{m}^{2} \text { per day }\right)\end{array}$} \\
\hline & Before & After & Before & After & Before & After & Before & $\ddot{A}$ fter \\
\hline $\begin{array}{l}\text { Salt-losers } \\
\text { Nonsalt-loser }\end{array}$ & $\begin{array}{l}364 \\
3 \cdot 6\end{array}$ & $\begin{array}{l}27 \\
1 \cdot 0\end{array}$ & $\begin{array}{l}3 \cdot 1 \\
0 \cdot 4\end{array}$ & $\begin{array}{l}1 \cdot 0 \\
0.6\end{array}$ & $\begin{array}{l}3 \cdot 3 \\
2 \cdot 2\end{array}$ & $\begin{array}{l}1 \cdot 03 \\
0 \cdot 57\end{array}$ & $\begin{array}{l}25 \\
21\end{array}$ & $\begin{array}{l}25 \\
21\end{array}$ \\
\hline
\end{tabular}

Mean values are shown. See Table 2 for conversion factors. 

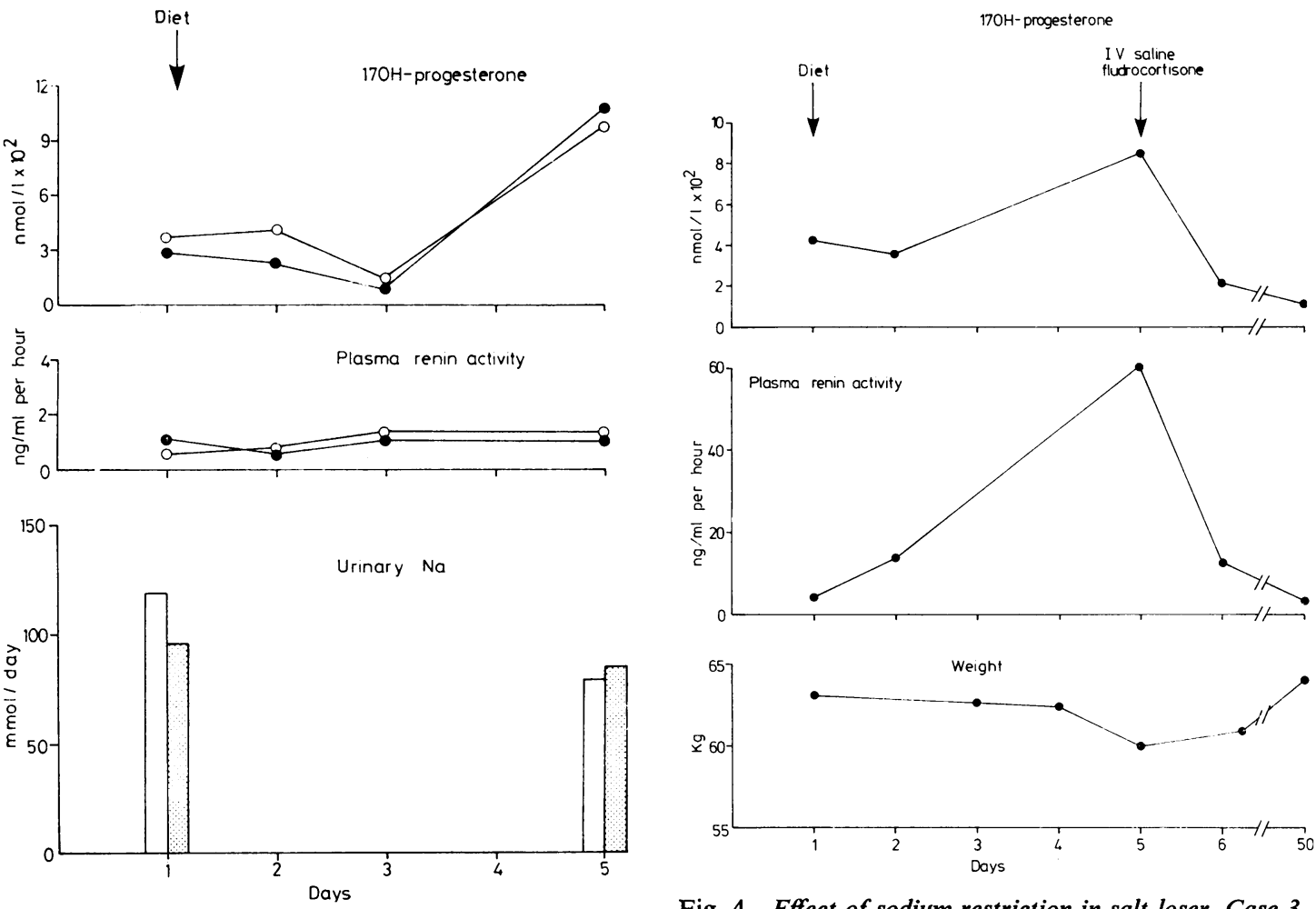

Fig. 3. Effect of sodium restriction in 2 salt-loser's,

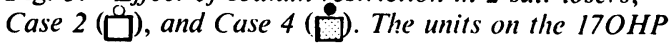
ordinate are increased by $10^{2}$.

during this time. The mean plasma 170H-progesterone concentration was now less than $30 \mathrm{nmol} / \mathrm{l}$ $(9 \cdot 4 \mathrm{ng} / \mathrm{ml})$, considered normal for adequately treated CAH patients (Chaussain et al., 1974; Hughes, 1977). Plasma testosterone concentrations and levels of plasma renin activity were also normal. During this time, 2 female salt-losers had started menstruating.

\section{Discussion}

This study confirms the suggestion that older children with salt-losing CAH can tolerate a reduction or even a cessation in mineralocorticoid treatment. However, this is compensated for by a high salt intake. The excessive sodium intake may be harmful over a long period. In their study of 3 children with hypoaldosteronism, Hamilton et al. (1976) suggested that in the face of sodium depletion, continuing a high sodium intake may have the effect of producing a high filtered water load in the kidney. This may in turn reduce renin production and hence the stimulus for aldosterone

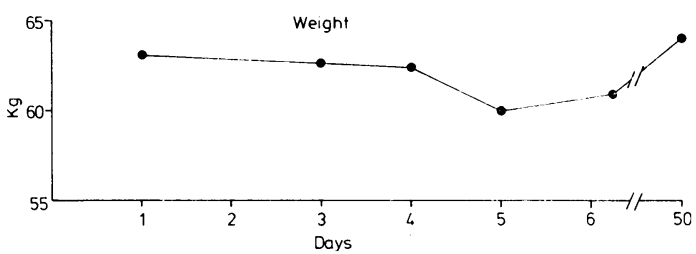

Fig. 4 Effect of sodium restriction in salt-loser, Case 3. Urinary Na values are not shown in this figure. The units on the $17 O H P$ ordinate are increased by $10^{2}$.

secretion. In such a situation, it is more rational to increase sodium reabsorption using a salt-retaining hormone. A high salt intake in childhood may be associated with the subsequent development of hypertension in adult life (Rose, 1977).

In this study, persistent salt depletion was suggested by increased levels of plasma renin activity in all but one of the salt-losers, despite normal serum electrolytes. This agrees with previous observations that measurement of plasma renin activity is an extremely sensitive index of sodium balance in salt-wasting disorders such as $\mathrm{CAH}$ (Dillon and Ryness, 1975; Hughes and Winter, 1977). All the salt-losers showed markedly raised plasma concentrations of $170 \mathrm{H}$-progesterone, indicating poor control, although they were receiving a hydrocortisone dose $\left(25 \mathrm{mg} / \mathrm{m}^{2}\right.$ per day) considered appropriate for maintenance therapy (Brook et al., 1974; Hughes and Winter, 1976). Limal et al. (1977) have also recently demonstrated raised concentrations of plasma renin activity, 17OHprogesterone, and aldosterone in a group of saltlosers treated only with hydrocortisone. 
Two female salt-losers in our study had increased plasma concentrations of testosterone. This was not surprising in view of the significant correlation between plasma concentrations of $17 \mathrm{OH}$-progesterone and testosterone in prepubertal and adolescent female CAH patients (Hughes and Winter, 1978). Persistently raised plasma testosterone concentrations in adolescent girls may result in menstrual disorders and possibly in reduced fertility (Kirkland et al., 1974). It may not have been mere coincidence, therefore, that these two female salt-losers started menstruating after fludrocortisone therapy and a return to normal plasma testosterone concentrations.

Salt restriction exaggerated mineralocorticoid deficiency in these salt-losers. The nonsalt-loser (Case 5) and one salt-loser (Case 1) were both able to reduce urinary sodium excretion in response to a low sodium diet, although compared with the controls, they both showed a greater rise in plasma renin activity. Two other salt-losers in our study (Cases 2 and 4) failed to suppress urinary sodium excretion while on the diet. Their high plasma $170 \mathrm{H}-$ progesterone concentrations increased still further, but no rise in plasma renin activity was demonstrated owing to an error in sampling technique. Salt restriction precipitated an adrenal crisis in one patient (Case 3) who required parenteral saline therapy. This patient and the boy excluded from the study because of an episode of gastroenteritis are examples of a severer degree of salt-wasting. The results suggest a variable degree of salt deficiency even within the small group of salt-losers examined in this study. Some patients are at serious risk of developing a life-threatening adrenal crisis if their salt intake is restricted.

What factors contribute to poor control in these salt-losing patients? There is evidence that infusion of angiotensin II (a polypeptide stimulated by increased plasma renin activity) can directly stimulate ACTH release in normal subjects (Rayyis and Horton, 1971). A recent study of sodium balance in $\mathrm{CAH}$ showed a significant correlation between plasma concentrations of ACTH and plasma renin activity (Rösler et al., 1977). The degree of ACTH stimulation was proportional to the amount of sodium loss. Salt depletion may itself result in chronic 'stress' and an enhanced ACTH production. The effect of increased ACTH production from whatever cause is an increased secretion of adrenal steroid precursors in $\mathrm{CAH}$ - such as progesterone, $17 \mathrm{OH}$-progesterone, and $16 \mathrm{OH}$-progesterone. These corticosteroids, when secreted in excess, have natriuretic activity in humans (Janoski, 1977). Their sodium-losing effect is probably through a competitive inhibition of aldosterone in the renal tubule, which explains the increased aldosterone production rates documented in nonsalt-losing $\mathrm{CAH}$ patients (Bartter et al., 1968).

In our patients, adding fludrocortisone to their treatments resulted in normal plasma concentrations of $17 \mathrm{OH}$-progesterone, testosterone, and plasma renin activity. The dose of fludrocortisone $(100 \mu \mathrm{g})$ would not have provided sufficient glucocorticoid effect to account for this improvement. It must be concluded, therefore, that as glucocorticoid therapy remained unchanged throughout this study, these salt-losers were chronically salt depleted and improved after mineralocorticoid therapy. Grant $e t$ al. (1977) added fludrocortisone to the treatment of a larger group of salt-losers. Not all their patients responded with a decrease in plasma steroid and plasma renin concentrations. However, only $50 \mu \mathrm{g}$ fludrocortisone was used and the patients were studied again after one month of treatment. Our results show conclusively that salt-losing $\mathrm{CAH}$ patients continue to require salt-retaining hormones throughout childhood and early adult life. Achieving normal sodium balance in such patients may well allow a reduction in glucocorticoid therapy and thereby an improvement in growth potential.

We thank Miss S. Chick, KRUF Institute of Renal Disease, Cardiff Royal Infirmary, for performing the assays of plasma renin activity. The technical assistance from members of the Supraregional Assay Service Laboratory in the Tenovus Institute is greatly appreciated. I. A. H. acknowledges the support of the Medical Research Council of Canada during the course of this study.

\section{References}

Bartter, F. C., Henkin, R. I., and Bryan, G. T. (1968). Aldosterone hypersecretion in 'non-salt-losing' congenital adrenal hyperplasia. Journal of Clinical Investigation, 47, 1742-1752.

Brook, C. G. D., Zachmann, M., Prader, A., and Mürset, G. (1974). Experience with long-term therapy in congenital adrenal hyperplasia. Journal of Pediatrics, 85, 12-19.

Chaussain, J-L., Estrada, Y., Roger, M., Tea, N. T., Scholler, R., Canlorbe, P., and Job, J-C. (1974). La 17-OH progestérone plasmatique. Mesure chez l'enfant normal et dans les hyperplasies surrénales congénitales par bloc de la 21-hydroxilation. Nouvelle Presse Medicale, 3, 2621-2624.

Dillon, M. J., and Ryness, J. M. (1975). Plasma renin activity and aldosterone concentration in children. British Medical Journal, 4, 316-319.

Grant, D. B., Dillon, M. J., Atherden, S. M., and Levinsky, R. J. (1977). Congenital adrenal hyperplasia: renin and steroid values during treatment. European Journal of Pediatrics, 126, 89-96.

Haber, E., Koerner, T., Page, L. B., Kliman, B., and Purnode, A. (1969). Application of a radioimmunoassay for angiotensin I to the physiologic measurements of plasma renin activity in normal human subjects. Journal of Clinical Endocrinology and Metabolism, 29, 1349-1355. 
Hamilton, W., McCandless, A. E., Ireland, J. T., and Gray, C. E. (1976). Hypoaldosteronism in three sibs due to 18-dehydrogenase deficiency. Archives of Disease in Childhood, 51, 576-583.

Hillier, S. G., Brownsey, B. G., and Cameron, E. H. D. (1973). Some observations on the determination of testosterone in human plasma by radioimmunoassay using antisera raised against testosterone-3-BSA and testosterone-11 $\alpha$-BSA. Steroids, 21, 735-754.

Hughes, I. A. (1977). Diagnosis and management of congenital adrenal hyperplasia. MD thesis, p. 113, University of Wales.

Hughes, I. A., and Winter, J. S. D. (1976). The application of a serum $17 \mathrm{OH}$-progesterone radioimmunoassay to the diagnosis and management of congenital adrenal hyperplasia. Journal of Pediatrics, 88, 766-773.

Hughes, I. A., and Winter, J. S. D. (1977). 17-Hydroxyprogesterone and plasma renin activity in congenital adrenal hyperplasia. In Congenital Adrenal Hyperplasia, pp. 141156. Edited by P. A. Lee, L. P. Plotnick, A. A. Kowarski, and C. J. Migeon. University Park Press: London.

Hughes, I. A., and Winter, J. S. D. (1978). The relationships between serum concentrations of $170 \mathrm{H}$-progesterone and other serum and urinary steroids in patients with congenital adrenal hyperplasia. Journal of Clinical Endocrinology and Metabolism, 46, 98-104.

Janoski, A. H. (1977). Naturally occurring adrenal steroids with salt-losing properties: relationships to congenital adrenal hyperplasia. In Congenital Adrenal Hyperplasia, pp. 99-112. Edited by P. A. Lee, L. P. Plotnick, A. A. Kowarski, and C. J. Migeon. University Park Press: London.
Kirkland, J., Kirkland, R., Librik, L., and Clayton, G. (1974). Serum gonadotrophin levels in female adolescents with congenital adrenal hyperplasia. Journal of Pediatrics, 84, 411-414.

Limal, J-M., Rappaport, R., and Bayard, F. (1977). Plasma aldosterone, renin activity, and 17 $\alpha$-hydroxyprogesterone in salt-losing congenital adrenal hyperplasia. I. Response to ACTH in hydrocortisone treated patients and effect of $9 \alpha$-fluorocortisol. Journal of Clinical Endocrinology and Metabolism, 45, 551-559.

Newns, G. H. (1974). Congenital adrenal hyperplasia. Archives of Disease in Childhood, 49, 1-3.

Rayyis, S. S., and Horton, R. (1971). Effect of angiotensin II on adrenal and pituitary function in man. Journal of Clinical Endocrinology and Metabolism, 32, 539-546.

Rose, G. A. (1977). Epidemiology of familial factors and salt intake in man. Postgraduate Medical Journal, 53, Supplement 2, 139-143.

Rösler, A., Levine, L. S., Schneider, B., Novogroder, M., and New, M. I. (1977). The interrelationships of sodium balance, plasma renin activity, and ACTH in congenital adrenal hyperplasia. Journal of Clinical Endocrinology and Metabolism, 45, 500-512.

Correspondence to Dr I. A. Hughes, Department of Child Health, Welsh National School of Medicine, Heath Park, Cardiff CF4 4XN.

Received 5 October 1978 